\title{
Relative Growth Rates of the Noble Pen Shell Pinna nobilis Throughout Ontogeny Around the Balearic Islands (Western Mediterranean, Spain)
}

\author{
Álvarez \\ Source: Journal of Shellfish Research, 31(3):749-756. 2012. \\ Published By: National Shellfisheries Association \\ DOI: http://dx.doi.org/10.2983/035.031.0319 \\ URL: http://www.bioone.org/doi/full/10.2983/035.031.0319
}

Author(s): Iris E. Hendriks, Lorena Basso, Salud Deudero, Miguel Cabanellas-Reboredo and Elvira

BioOne (www.bioone.org) is a nonprofit, online aggregation of core research in the biological, ecological, and environmental sciences. BioOne provides a sustainable online platform for over 170 journals and books published by nonprofit societies, associations, museums, institutions, and presses.

Your use of this PDF, the BioOne Web site, and all posted and associated content indicates your acceptance of BioOne's Terms of Use, available at www.bioone.org/page/terms_of_use.

Usage of BioOne content is strictly limited to personal, educational, and non-commercial use. Commercial inquiries or rights and permissions requests should be directed to the individual publisher as copyright holder. 


\title{
RELATIVE GROWTH RATES OF THE NOBLE PEN SHELL PINNA NOBILIS THROUGHOUT ONTOGENY AROUND THE BALEARIC ISLANDS (WESTERN MEDITERRANEAN, SPAIN)
}

\author{
IRIS E. HENDRIKS, ${ }^{1 *}$ LORENA BASSO,${ }^{1}$ SALUD DEUDERO, ${ }^{2}$ \\ MIGUEL CABANELLAS-REBOREDO ${ }^{1}$ AND ELVIRA ÁLVAREZ ${ }^{3}$ \\ ${ }^{1}$ IMEDEA (CSIC-UIB), Instituto Mediterráneo de Estudios Avanzados, C/ Miquel Marqués 21, 07190 \\ Esporles (Mallorca), Spain; ${ }^{2}$ Instituto Español de Oceanografía (IEO)-Centro Oceanográfico de \\ Baleares, Muelle de Poniente s/n, Apartado 291,07015 Palma de Mallorca, Spain; ${ }^{3}$ Direcció General de \\ Pesca, Conselleria d'Agricultura i Pesca, Govern de les Illes Balears, C/ Foners, 10, 07006 Palma de \\ Mallorca, Spain
}

\begin{abstract}
In this study, we evaluated the growth of adults and juveniles of the endangered noble pen shell Pinna nobilis, calculated the growth rates of newly recruited juveniles, and described relative directional growth during ontogeny. We described growth using posterior adductor muscle scars (PAMS) and fit of the von Bertalanffy growth curve for adult population data at shallow depths $(5-10 \mathrm{~m})$ around the Mallorca and Ibiza islands, and compared the parameters with other Mediterranean populations. Populations around Mallorca could be fitted according to the von Bertalanffy function $L_{t}=65.31\left(1-\mathrm{e}^{-0.11(t+0.53)}\right)$, whereas for Ibiza the function was $L_{t}=154.55\left(1-\mathrm{e}^{-0.03(t+4.31)}\right)$. We compared first-year growth rates obtained in the laboratory and from field collections with newly settled individuals. We found that experimentally evaluated growth rates of juveniles in the laboratory of $0.18 \mathrm{~mm} /$ day are low compared with minimum values obtained in the field, which range, on average, from $0.28-0.32$ $\mathrm{mm}$ /day, indicating food availability can limit growth. Furthermore we investigated relative allometric growth patterns during ontogeny using a unique data set ranging from measurements of newly recruited juveniles with shell length less than $1 \mathrm{~cm}$ to measurements on adult shells of $69.8 \mathrm{~cm}$ length. Fitting a sigmoidal function to our data and solving for the allometric exponent $b$, we found 3 distinct growth periods: preferential growth in the length direction up to $5.82 \mathrm{~cm}$ in shell length, then widening of the shell up to $14.64 \mathrm{~cm}$, after which the shape of the shell becomes more elongated once again.
\end{abstract}

KEY WORDS: Pinna nobilis, pen shell, growth rate, allometric growth, von Bertalanffy growth curve

\section{INTRODUCTION}

The pen shell Pinna nobilis (Linnaeus, 1758) is one of the largest mollusc species, reaching total anteroposterior lengths of up to $1.2 \mathrm{~m}$ (Zavodnik et al. 1991, Richardson et al. 1999, García-March et al. 2007a). The species is endemic to the Mediterranean Sea, where it typically occurs in association with Posidonia oceanica (L.) Delile meadows. Pen shells live partially buried upright in the sand, anchored by their numerous byssus filaments to the rhizomes and shoots of $P$. oceanica. The population numbers of the bivalve $P$. nobilis are currently in decline (Centoducati et al. 2007) and the pen shell is subject to strict protection as an endangered species under European Council Directive 92/43/EEC (EEC 1992). The pen shell $P$. nobilis is long-lived, achieving a life span in excess of $20 \mathrm{y}$ (Butler et al. 1993, Richardson et al. 1999, Galinou-Mitsoudi et al. 2006). The full life cycle of the pen shell is still understudied; for example, the mortality of larvae is unknown and, for juveniles, there is very little information available (Katsanevakis 2007). Butler et al. (1993) state that larvae of the fan mussel have a life span of 5-10 days, and they have, like most bivalve species, a highly variable recruitment (Katsanevakis 2007).

Little is known about growth during the direct period after settlement and metamorphosis, although growth is fast during the first $2-3 \mathrm{y}$, and much slower thereafter, according to a $10-\mathrm{y}$ study of the growth of $P$. nobilis in the French Mediterranean (Vicente et al. 1980, Moreteau \& Vicente 1982).

*Corresponding author. E-mail: iris@imedea.uib-csic.es DOI: $10.2983 / 035.031 .0319$
A disputed method to estimate the age and growth of related Pinna bicolor in South Australia relies on the interpretation of putative adductor muscle scars, which represent seasonal migration of the adductor muscle as the length of the shell increases (Butler \& Brewster 1979, Butler 1987). These posterior adductor muscle scars (PAMS) represent a year of life, but not all years are discernible as PAMS on the inner surface of the shell (García-March \& Marquez-Aliaga 2007b, Garcia-March et al. 2011). The inner shell surfaces of $P$. nobilis from the Spanish Mediterranean also show PAMS. In general, a linear relationship exists between shell growth rate and water temperature (Richardson et al. 1999). After settlement, shell growth is rapid, reaching a maximum rate during the summer high water temperatures. During a similar period of increasing water temperatures in the second year (May and June), shell accretion appears to be marginally slower than at the same time the previous year, and it correlates with the appearance of the "first" ring on the adductor muscle scar. Therefore, the first year is not accounted for by a PAMS, as corroborated with stable isotope data (Richardson et al. 1999). Estimates of the growth rates of the pinnids using adductor muscle scar rings should take into account a missing first-year ring, as well as the fact that not all years are visible as PAMS. However, evaluating PAMS can be useful to make comparisons among populations to explore qualitative differences in growth. During ontogeny, growth is characterized by changes in proportion as well as size, called allometric growth. In pen shell populations on the Tunisian coast, there was a breakpoint at a shell length $\approx 18 \mathrm{~cm}$, corresponding to a widening of the shell after which growth became elongated (Rabaoui et al. 2007). Such a change in the growth trajectory might be a useful source of information about life 
history events of the pen shell or a fast ecological change. A comparison with other regions, like the Balearic Islands, might reveal this change in growth pattern as specific for the species or highly regional, connected to local changes.

In this study, our main objectives were (1) to evaluate, for the first time, growth rates of $P$. nobilis ranging the full life spanfrom newly settled recruits to adults - and (2) to compare differences in growth in $P$. nobilis populations around the Balearic Islands. We used laboratory measurements and field observations of juvenile and adult individuals for this aim. We measured growth of young individuals of younger than $1 \mathrm{mo}, 3 \mathrm{mo}$, and 6 mo of age caught in collectors directly after recruitment. Furthermore, we kept juveniles in aquaria subjected to a known food regime. With our data set, which contains a large size range of shell size, we focus on relative allometric growth throughout ontogeny and evaluate discontinuities in preferential growth direction.

\section{MATERIALS AND METHODS}

\section{Study Site}

We sampled 5 sites around the island of Mallorca (depth, 5-6 m), Magalluf ( $\left.39^{\circ} 30.1^{\prime} \mathrm{N}, 2^{\circ} 32.36^{\prime} \mathrm{E}\right)$, Cala d'Or $\left(39^{\circ} 22.164^{\prime} \mathrm{N}\right.$, $3^{\circ} 13.887^{\prime}$ E), Es Cargol (39 $16.394^{\prime}$ N, 3⒉476' E), St. Maria (Cabrera), and Pollença $\left(39^{\circ} 53.792^{\prime} \mathrm{N}, 3^{\circ} 05.523^{\prime}\right.$ E; Fig. 1). Additional data for adult valves were obtained by measurements of shells of individuals obtained alive from Ibiza: Talamanca, Esponja, and Espardell (7-25 m), and Dragonera (Mallorca, 7-10 m) by Cabanellas-Reboredo et al. (2009b).

\section{Age-Size Relationship of Adult Pinna nobilis}

During 2006 and 2007, we collected 70 valves from dead individuals in the meadows around the Balearic Islands (Fig. 1), consisting out of 2 valves stuck together or without too much epiphyte cover. In addition, from the same meadows, we used the valves of 16 specimen originally collected alive for another study, see Cabanellas-Reboredo et al. (2009b). Shell length ranged from $8.5-69.8 \mathrm{~cm}$. We measured the distance from the posterior end of the anterior adductor muscle scar to the last ring of the PAMS deposited at the leading edge of the dorsal nacre lobe (Fig. 2B in Richardson et al. (1999)).

There is a good linear relationship between shell length and the youngest leading edge of the dorsal nacre lobe (Richardson et al. 1999). Therefore, fitting an equation between these 2 dimensions, it is possible to extrapolate the corresponding shell lengths when each PAMS was deposited. Even if age of individuals cannot be established reliably by counting the number of scars, we relate the number of PAMS to shell length adding 1 for the first year when no scarring occurs to compare growth patterns in Mallorca with other sites in the Mediterranean. We fitted growth curves based on the von Bertalanffy growth function $L_{t}=L_{\infty}\left(1-\mathrm{e}^{-k(t-t 0)}\right)$ with the FSA package in R (Ogle 2010), where $L$ is shell length, $k$ is a rate constant, and $t$ is the number of PAMS +1 . The von Bertalanffy growth model (von Bertalanffy 1938) is the most commonly applied among lengthage models and, although other models have been used, it seems to be the most fitting for growth of $P$. nobilis, as a comparison among models for 5 populations along the Tunisian coast demonstrated (Rabaoui et al. 2007).

\section{Growth in Juvenile Pinna nobilis}

\section{Field}

Recruits were sampled at the same field sites around Mallorca where the adult valves where collected (Fig. 1). Mesh bags, providing a large surface and substratum similar to $P$. oceanica rhizomes, were used to collect recruits. Collectors were adjusted from Type II used in the same area by CabanellasReboredo et al. (2009a). Every collector consisted of a concrete block moored at a 5-m depth in natural sand patches within the seagrass meadow to cause minimal disturbance to the plants. A rope was attached to the blocks, and a subsurface buoy was used to keep the bags afloat and to mark the collector. Three collector bags, each with their own mooring, were suspended at depths of 2-3 $\mathrm{m}$ at each site, with approximately $10 \mathrm{~m}$ between each mooring. Subsurface buoys were used to avoid hindering navigating ships and unwanted removal by third parties. Polyethylene mesh bags $(0.7 \times 0.4 \mathrm{~m}$ big, with a mesh width of $0.01 \times$ $0.01 \mathrm{~m}$ ) were attached to the rope at intervals between $0.5 \mathrm{~m}$ and $1.0 \mathrm{~m}$. Inside each bag, 13 -m-long $\times 0.1$-m-wide thin onion nets with a mesh width of $0.005 \times 0.005 \mathrm{~m}$ were placed to increase the available recruitment surface.

Starting at the beginning of summer (late June), these bags were changed every month, then frozen until further analysis. One set of bags for each site was left for the full sampling period ( $3 \mathrm{mo}$ ), and at 1 site (Pollença), 15 additional bags were left for 6 mo total. After defrosting, bags were cut in manageable pieces and flushed under tap water using a brush. Organisms were picked out with tweezers. Length and width of visible juveniles were measured with a digital caliper. Small recruits were collected on a $200-\mu \mathrm{m}$ sieve after filtering the processed water. Small postlarvae were isolated and counted under a microscope (Stemi 2000C, Zeiss). Organism size was obtained from calibrated measurements of photos acquired using a stereomicroscopic camera (AxioCam MRc5, Zeill; with AxioVision 40 V4.3.0, Carl Zeiss Imaging solutions software) and was processed using ImageJ software (ImageJ Java 1.6.010). Samples were preserved on alcohol. From the exact submersion period of the bags and larval size, a minimum growth rate is estimated, assuming that the largest individual in each bag settled on the first submersion day of trap deployment and grew until recollection.

\section{Laboratory}

To estimate growth rates of juvenile recruits in the laboratory, we submerged collector bags in Pollença (Fig. 1) from June 24 until September 16, 2010 (a total of 85 days). The 63 individuals collected in these field collectors were transferred to a controlled laboratory environment. They were suspended for 13 days in a 100-L tank in small individual mesh bags, keeping them upright but permitting the exchange of water and food. Juveniles were fed daily an equal mixture of Rhinomonas and Tetraselmis sp., species commonly used in shellfish cultures (Coutteau \& Sorgeloos 1992), with a final concentration of 1,000 cells $/ \mathrm{mL}$. Temperature was kept constant at $26^{\circ} \mathrm{C}$, the average summer (June to October) water temperature around Mallorca and the temperature at the time of collection. Individual shell length and width were measured at the beginning and end of the experiment.

\section{Allometric Growth Patterns}

The relationship between age and unburied length has little informative value in field studies because the amount of buried 

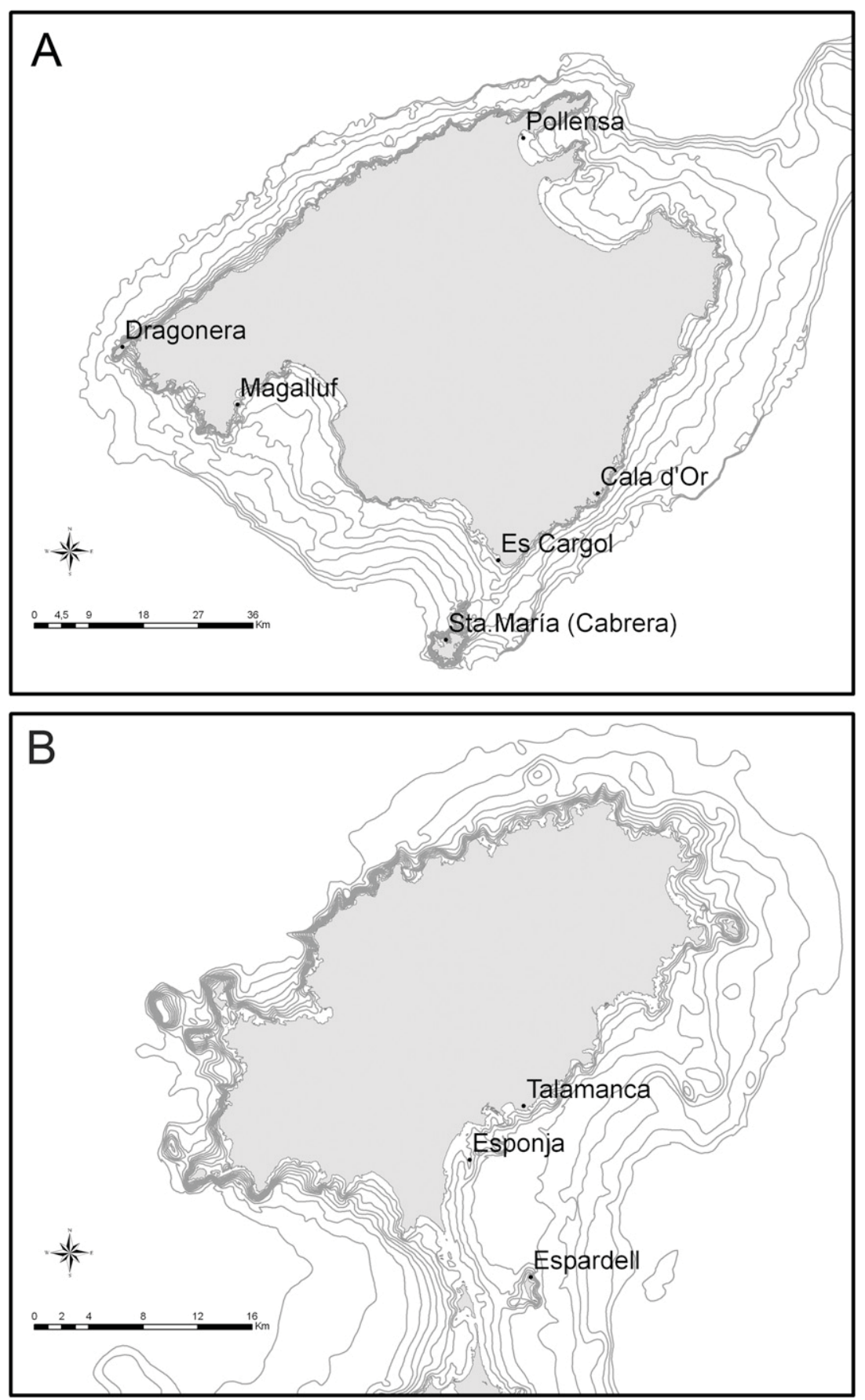

Figure 1. Geographical location and sample sites of the study area in the Balearic Islands (western Mediterranean). (A) Mallorca. (B) Ibiza. Continuous lines show isobaths.

shell is highly variable among individuals. Therefore, we generally use a length-width relationship to back-calculate probable age of individuals measured in the field, unlike García-March et al. (2002), who used a measurement of unburied shell parts together with an estimation of the length of the buried shell using an empirical equation (García-March \& Ferrer 1995). It is important to know changes in length-width relationships throughout ontogeny of the organism because this adds accuracy to age estimates of monitored individuals in the field. Because growth is often accompanied by changes in proportion as well as size, the allometric equation $W=a L^{b}$ (Huxley 1932) should be used. In this equation, $W$ is shell width, $L$ is shell length, and exponent $b$ is a measure of the difference in growth rates of the shell parts. However, this classic model fails for pen shell growth because of the existence of a breakpoint in the growth trajectory (Rabaoui et al. 2007), and a more complex model of the form $\log W=f(\log L)$ should be used (Katsanevakis et al. 2007). We selected the quadratic model, assuming that nonlinearity exists in the relationship of width and length: $\ln W=a_{1}+i_{1} \ln L+b_{2}$ $(\ln L)^{2}$, with the allometric exponent $b$ calculated as described in 

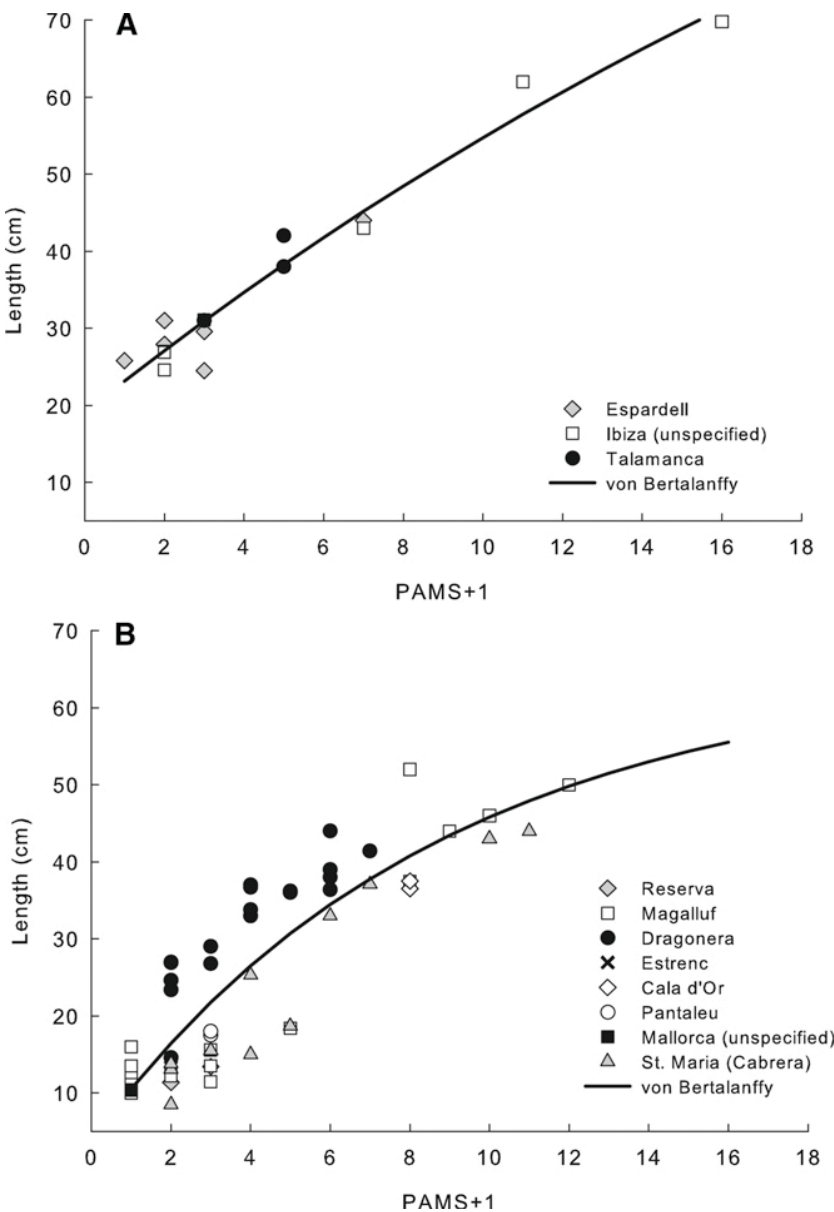

Figure 2. (A, B) Von Bertalanffy growth curve for pinnids around the islands of Mallorca (A) and Ibiza (B). PAMS, posterior adductor muscle scars.

Katsanevakis et al. (2007) as $b=b_{1}+2 b_{2} \ln L$. The exponent $b$ is a measure of the difference in the growth rates of the 2 parts of the body. When $b$ is less than 1 , the type of growth is described as negative allometric; when $b$ is greater than 1 , growth type is described as positive allometric; when $b$ equals 1 , growth is labeled isometric. However, our data ranges from size measurements of the smallest stages $(<1 \mathrm{~cm})$ to very large adults, and the quadratic model, only solve for the allometric exponent $b$ for 1 discontinuity in allometric growth, and we suspect more than 1 discontinuity. For these reasons, we also explored another model - a sigmoidal function $f=a / 1+\exp \left(-\left(x-x_{0}\right) / b_{1}\right)$ - and solved for $b$ numerically (as first derivative of the function) in agreement with Katsanevakis et al. (2007). Measurements from a total of 390 individuals (adults and recruits) were used to fit the model.

\section{RESULTS}

\section{Adult Growth Rates}

A Tukey-Kramer test showed that there was no difference in the relationship between PAMS and shell length for sites around the island of Mallorca; in Ibiza only 3 sites were sampled. The relationship between PAMS and length was different for Ibiza and Mallorca ( $t$-test, $t=-4.78, P>0.001$ ). Esponja (depth, 20-25 m) was different from other sampled sites in Ibiza, such as
Talamanca and Espardell (depth, 7-10 m depth), so we excluded the 4 measurements from Esponja. Populations around the island of Ibiza could be fitted according to the von Bertalanffy function $L_{t}=154.55\left(1-e^{-0.03 t+4.31}\right)$, whereas for Mallorca the function was $L_{t}=65.31\left(1-e^{-0.11(t+0.53)}\right)$; Fig. 2). Note that the asymptotic length $\left(L_{\infty}\right)$ reached by the bivalves is not significant in Ibiza (Table 1) and we probably lack data points for a good estimation of growth in this island.

\section{Juvenile Growth Rates}

At the beginning of the experiment, the smallest Pinna in our laboratory setup was $1.41 \mathrm{~cm}$ long and the largest measured $5.57 \mathrm{~cm}$. During a period of 13 days, juveniles grew, on average, $0.18 \pm 0.021(\mathrm{SE}) \mathrm{mm} /$ day $(n=63)$ in the laboratory. There was no significant relationship between the amount grown and the initial size $\left(y=0.036 x+1.308, R^{2}=0.04\right)$ as the slope of the regression was not significantly different from $0(a=0.036 \pm$ $0.0251, t=1.43, P=0.16, n=56$ ).

In situ juvenile minimal growth rates (Table 2) differed considering month of submersion $\left(\mathrm{F}_{d f=2}=6.70, P<0.01\right)$ but not collection site $\left(\mathrm{F}_{d f=4}=2.26, P=0.11\right)$, although Pollença seems to be different from the other sites in parameter estimation $(t=2.7, P=0.02)$. The average monthly minimum growth rate for all sites as inferred from the largest individual in each collector was $0.32 \pm 0.069 \mathrm{~mm} /$ day $(n=34)$, with a maximum of $0.85 \mathrm{~mm} /$ day in September in Pollença. The growth rate of individuals that had been submersed the entire summer $(3 \mathrm{mo})$ was $0.28 \pm 0.069 \mathrm{~mm} /$ day $(n=12)$.

After 6 mo of submersion, calculated growth rates were similar to the subjective growth estimated from PAMS in adult shells (Fig. 3, inset): $0.29 \pm 0.008 \mathrm{~mm} /$ day $(n=120)$ versus $0.29 \mathrm{~mm} /$ day, as inferred from the von Bertalanffy fit (Fig. 3, Table 1). However, adult growth is subjective because not all years are visible as a PAMS, and therefore the estimated value is an overestimation of the growth rate. Because of the high variability in juvenile growth rates among months, growth rates measured over $1 \mathrm{mo}, 3 \mathrm{mo}$, and $6 \mathrm{mo}$ are not significantly different (Tukey-Kramer HSD), with the highest variation in the first month corresponding to the highest average growth rate.

\section{Morphometry}

The data of the length-width relationship (log transformed) of the pen shells of Mallorca indicate possible breakpoints from

TABLE 1.

Parameters of the von Bertalanffy fit as performed in $\mathrm{R}$ with the FSA package (Ogle 2011).

\begin{tabular}{crrrl}
\hline \hline & Estimate & \multicolumn{1}{c}{ SE } & $\boldsymbol{t}$ Value & \multicolumn{1}{c}{$\boldsymbol{P ( > | \boldsymbol { t } | )}$} \\
\hline Mallorca & & & & \\
$L_{\infty}$ & 65.31401 & 17.92615 & 3.644 & $0.00063^{* * * *}$ \\
$K$ & 0.11480 & 0.05962 & 1.925 & 0.05977 \\
$t_{0}$ & -0.52821 & 0.62637 & -0.843 & 0.40301 \\
Ibiza & & & & \\
$L_{\infty}$ & 154.54687 & 95.88768 & 1.612 & 0.1310 \\
$K$ & 0.03053 & 0.02730 & 1.119 & 0.2836 \\
$t_{0}$ & -4.31230 & 1.51107 & -2.854 & $0.0136^{*}$ \\
\hline
\end{tabular}

$L$, length; $K$, rate constant; $t$, number of posterior adductor muscle scars. *, indicates a significance of $P<0.05, * * *, P<0.001$ 
TABLE 2.

Mean juvenile growth rates (measured in millimeters per day \pm SD) estimated from field samples directly after recruitment around the island of Mallorca during the summer months.

\begin{tabular}{llllll}
\hline \hline Month & Pollença & St. Maria & Cala d'Or & Es Cargol & Magalluf \\
\hline July & $0.17 \pm 0.041$ & & $0.10 \pm 0.100$ & & \\
August & $0.42 \pm 0.018$ & 0.25 & & $0.33 \pm 0.028$ & $0.19 \pm 0.128$ \\
September & 0.85 & & 0.38 & $0.14 \pm 0.010$ & $0.42 \pm 0.043$ \\
Summer & $0.37 \pm 0.084$ & $0.27 \pm 0.056$ & 0.35 & $0.21 \pm 0.080$ & $0.19 \pm 0.060$ \\
\hline
\end{tabular}

Values for summer are from traps submerged during the full sampling period and are not an average of the values per month. When no value is given, there was no recruitment observed or a sample was missing (e.g., August in Cala d'Or).

juvenile through adult stages (Fig. 4A). Using a quadratic model, the relative growth in width was negative allometric $(b<1)$ up to a length size of $\approx 20 \mathrm{~cm}$, and then became positive allometric $(b>1)$ with continuously increasing $b$ (Fig. 4B). This means that during the first months after metamorphosis, and during the first few years, the organisms invest in growth along the length axis. Only when they reach ca. $20 \mathrm{~cm}$ in length growth is preferentially in width. However, through ontogeny the relationship between length and width is not stable, as recently metamorphosed postlarvae of $P$. nobilis do not have the same length-width relationship as adults (Fig. 4C). Using a quadratic relationship clearly means we miss the breakpoint that is visible around $5 \mathrm{~cm}$. Using a sigmoidal function (Fig. 4D) allowed us to estimate 2 discontinuities of the allometric exponent $b$ by solving the first derivative of the function. Using this model, we find negative allometric growth $(b<1)$ up to $5.82 \mathrm{~cm}$, after which there is a period of positive allometric growth, or preferential widening of the shell, up to $14.64 \mathrm{~cm}$. After this size, the shape becomes more and more elongated.

\section{DISCUSSION}

\section{Adult Growth Rates}

We found no apparent differences in growth rates between the 5 sampled sites around Mallorca, even when they were located

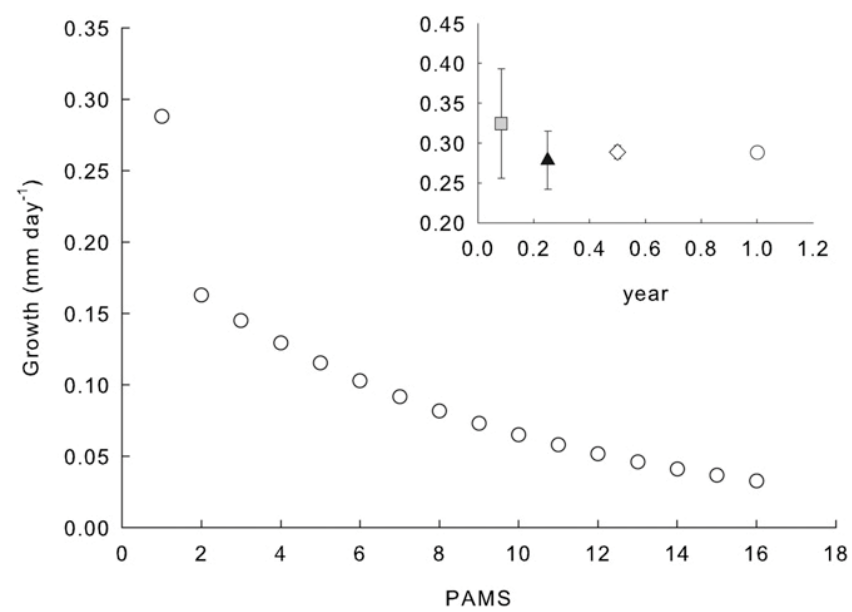

Figure 3. Growth rates for age classes around the island of Mallorca. (Inset) Growth rates for juveniles and the estimate for a 1-y-old specimen from the von Bertalanffy fit (large graph). $\bigcirc$, adults; $\square$, 1-mo-old juveniles; $\triangle$, 3-mo-old organisms; $\diamond$, 6-mo-old organisms. at different sides of the island (north, southeast, southwest, and east). Growth rates of populations of pinnids can be influenced by oceanographic differences among sites. Particle capture by filter feeders, for example, differs considerably among sites because of velocity and organic content of water currents (Shimeta \& Jumars 1991). Differences in feeding are reflected in the stable isotopic values of organism tissue. A stable isotope study of Pinna tissue (Cabanellas-Reboredo et al. 2009b) around the island of Mallorca showed differences in nitrogen but not in carbon for different sites. Based on these and our results, we assume the differences in food are unimportant among our sampling sites. Another factor influencing growth rate is temperature. Temperatures do differ among depths. In the archipelago of Cabrera, annual mean temperature at a depth of $5 \mathrm{~m}$ is $3.5 \pm 0.65^{\circ} \mathrm{C}$ warmer than at a depth of $35 \mathrm{~m}$ depth (E. Cebrian, pers. comm.; www.t-mednet.org), and growth rates could be influenced by this difference. Even among individuals of the same population, depth-related growth differences in absolute growth are found (García-March et al. 2007a). This might explain the different growth rates in Esponja (depth, 20-25 m; Ibiza), which caused us to exclude data from this site. The other sites in Ibiza were at 7-10 m, whereas the sites in Mallorca were at $5 \mathrm{~m}$. In simultaneous studies using the same sites in Mallorca we never observed differences in summer temperatures at $5 \mathrm{~m}$ depth (Hendriks et al. unpubl.), while there are more differences between the sites in Ibiza and Mallorca than depth (2-5 $\mathrm{m}$ difference) alone so this factor is probably not the most important.

The maximum estimated size obtained by the bivalves $\left(L_{\infty}\right)$ in our study was $65.31 \mathrm{~cm}$ for Mallorca and $154.55 \mathrm{~cm}$ for Ibiza (Fig. 2). The value for Ibiza was not significant in the model and indeed is disparate compared with literature values for Spanish Mediterranean populations: $37.59 \mathrm{~cm}$ for Moraira at a depth of $6 \mathrm{~m}$ (García-March et al. 2007a), $49.41 \mathrm{~cm}$ at Aguamarga (depth, 3-24 m), $45.27 \mathrm{~cm}$ at Rodalquilar (depth, 2-5 m), and $68.98 \mathrm{~cm}$ at Carboneras (depth, 4-17 m) (Richardson et al. 1999). Growth parameters of the von Bertalanffy growth curve can be quite imprecise when estimated on a data set without available large sizes close to the asymptotic length (Rabaoui et al. 2007), like their asymptotic length of a Tunisian population $\left(\mathrm{L}_{\infty}=104.3\right)$ or our values for Ibiza. The growth rate $(k)$ encountered for Mallorca $(-0.11)$ is low compared with Southeast Spain $(-0.2,-0.28,-0.22)$ (Richardson et al. 1999), where bivalves tend to reach a maximum length at a younger age. The value calculated for Ibiza $(-0.03)$ is very low, so much that we suspect this is an artefact caused by the fact that we have not collected enough data points. 

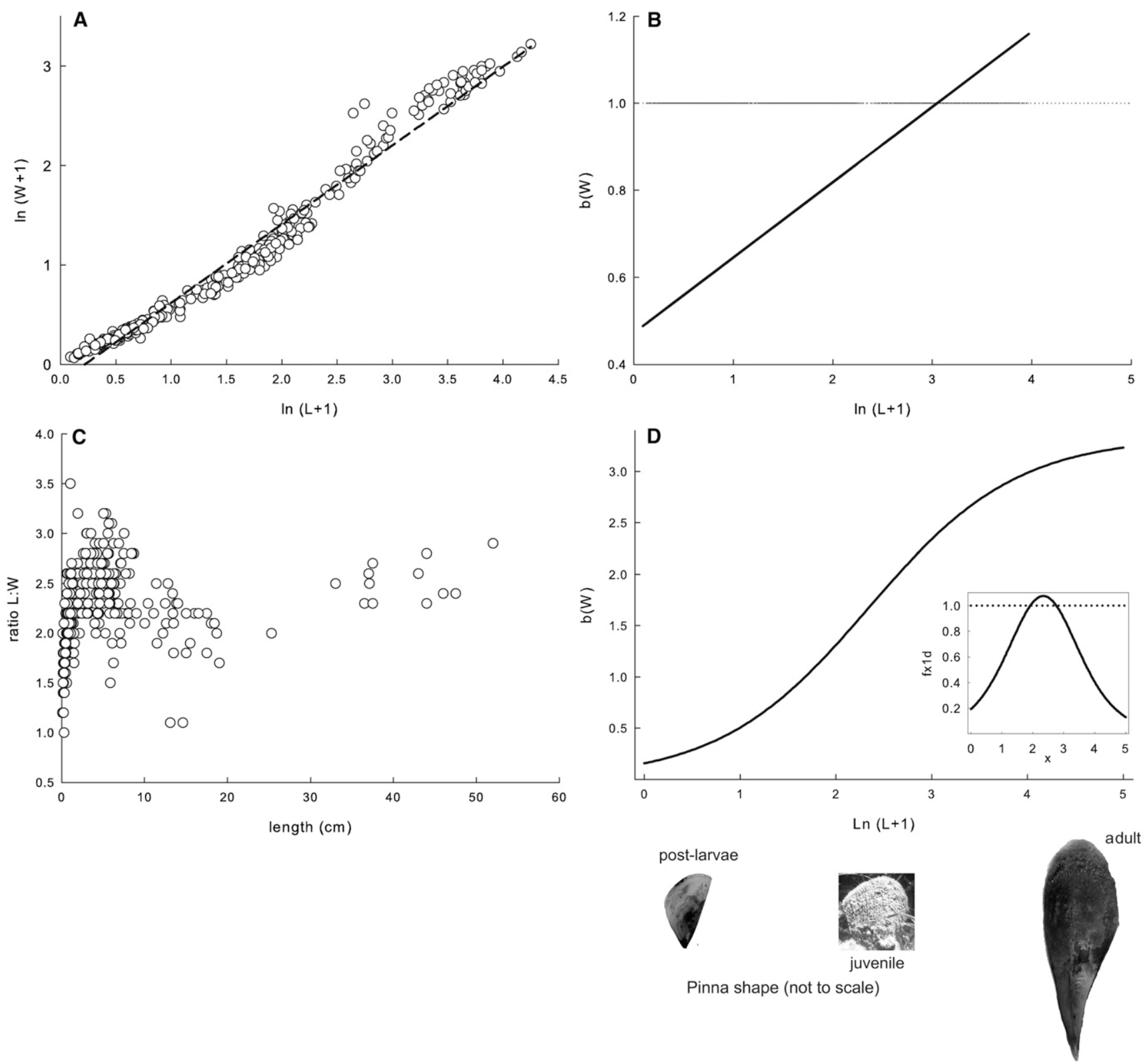

Figure 4. (A) Measured width (W) in centimeters in relation to shell length (L) of juvenile and adult Pinna nobilis around the island of Mallorca. Data are transformed as $\ln (x+1)$ because the smallest individuals measure less than $1 \mathrm{~cm}$. Regression line: $y=0.7914 x-0.1737\left(r^{2}=0.98\right)$. (B) Allometric exponent $b$ for the relative growth of shell $W$ versus $L$. (C) L:W ratio versus Length for juvenile and adult $P$. nobilis. (D) Sigmoidal model and allometric exponent $b$ based on this model (inset).

\section{Juvenile Growth Rates}

To our knowledge, this is the first study to measure growth reliably during the first month, first 3 mo, and first half year after recruitment (Table 2). In the literature, growth rates are historically reconstructed by the measurement of dead valves and the assumption of the relationship between growth (length) and PAMS (proxy for age). However, this leads to underestimation of an individual's age (García-March \& Marquez-Aliaga 2007b, Garcia-March et al. 2011). Because we can pinpoint the recruitment date, we have a reliable estimate of age to which to couple size. Because growth rate decreases during the life of the bivalves and is high during the first year, we assumed we would find even greater growth rates during the first months. However, we cannot demonstrate a significant difference in growth rates compared with averages over the first year, although there is an indication that, during the first month, growth rates $(0.32 \mathrm{~mm} /$ day $)$ are greater compared with those calculated for later dates $(0.28 \mathrm{~mm} /$ day $)$. The estimate obtained with direct measurements is in agreement with calculations from the von Bertalanffy fit on adult valves (Fig. 3), indicating that the estimate for the first year, when no scar is visible, might be better than for later years. Additional proof should be collected, however, because the method has been criticized for its accuracy and other methods less prone to observer error are available (Richardson et al. 2004). 
The laboratory results, when growth was low compared with growth in the field $(0.18 \mathrm{~mm} /$ day vs. $0.28 \mathrm{~mm} /$ day $)$, show that growth is food limited, as during the laboratory experiment, juveniles were fed only 1,000 algal cells/mL daily. The algal densities used commonly in bivalve hatchery production systems are $30-100$ times greater, ranging from $30-100 \times 10^{3}$ cells $/ \mathrm{mL}$ (Gosling 2007). Although optimal standard rations should have values between $50-200 \times 10^{3}$ cells/mL (Rico-Villa et al. 2006). Several studies confirm that algal densities lower than standard values can compromise juvenile and larval bivalve growth (Cahalan et al. 1989, Coutteau et al. 1994, Kheder et al. 2010).

With a database of measured length-width relationships of $P$. nobilis ranging from very small recruits of $<<1$ (0.094) $-69.8 \mathrm{~cm}$, corresponding to a range of individuals younger than 1 mo old to approximately 14 to 18 -y-old organisms, we had a unique set of data to investigate how length-width relationships change over time (Fig. 4). The sigmoidal model was able to resolve the growth patterns observed in young individuals up to $\mathrm{ca} .6 \mathrm{~cm}$ in length $(0.5 \mathrm{y}$ old $)$, which invest in growth along the vertical axis (elongation). From that point on (corresponding to their first spring), proportionally more effort is invested in the horizontal (width) direction until they reach ca. $15 \mathrm{~cm}$ length (corresponding to ca. $2 \mathrm{y}$ of age). After that, growth is again proportionally more important in the vertical direction until a stable relationship of $\mathrm{L}: \mathrm{W}=2.9$ is reached. We hypothesize that this first investment along the vertical axis serves for attachment purposes, as newly recruited Pinna during winter surveys are often found buried more than two thirds in the sand between Posidonia rhizomes. The results of our sigmoidal model resolve patterns of relative growth from very small recruits onward, whereas the upper limit of change of allometric growth (ca. $15 \mathrm{~cm}$ ) is slightly smaller than that observed by Rabaoui et al. (2007) at $\approx 18 \mathrm{~cm}$, and Katsanevakis et al. (2007) at $\approx 20 \mathrm{~cm}$. This could be caused by local differences in food supply, hydrodynamics, or predators.

\section{ACKNOWLEDGMENTS}

We thank Inés Mazarrasa for help processing the juvenile samples and are grateful for the help provided by D. H. Ogle, M. Fowler, and G. Tavecchia with estimating the parameters of the von Bertalanffy growth curve in $\mathrm{R}$. The research leading to these results has been funded by the Spanish government: contract no. CTM2009-07013; Project MedEICG and project 024/2010 of the Parques Nacionales call. I.E. H. was funded by a Juan de la Cierva grant (JCI-2007-123-844).

\section{LITERATURE CITED}

Butler, A. J. 1987. Ecology of Pinna bicolor Gmelin (Mollusca: Bivalvia) in Gulf St. Vincent, South Australia: density, reproductive cycle, recruitment, growth and mortality at three sites. Aust. J. Mar. Freshw. Res. 38:743-769.

Butler, A. J. \& F. J. Brewster 1979. Size distributions and growth of the fan-shell Pinna bicolor Gmelin (Mollusca: Eulamellibranchia) in South Australia. Aust. J. Mar. Freshw. Res. 30:25-39.

Butler, A., N. Vicente \& B. de Gaulejac. 1993. Ecology of the pterioid bivalves Pinna bicolor Gmelin and Pinna nobilis L. Mar. Life (Marseille) 3:37-45.

Cabanellas-Reboredo, M., S. Deudero, J. Alos, J. M. Valencia, D. March, I.E. Hendriks, \& E. Álvarez. 2009a. Recruitment of Pinna nobilis (Mollusca: Bivalvia) on artificial structures. Mar. Biodivers. Rec. 2:e126.

Cabanellas-Reboredo, M., S. Deudero \& A. Blanco. 2009b. Stableisotope signatures $\left(\mathrm{d}^{13} \mathrm{C}\right.$ and $\left.\mathrm{d}^{15} \mathrm{~N}\right)$ of different tissues of Pinna nobilis Linnaeus, 1758 (Bivalvia): isotopic variations among tissues and between seasons. J. Mollusc. Stud. 75:343-349.

Cahalan, J., S. Siddall \& M. Luckenbach. 1989. Effects of flow velocity, food concentration and particle flux on growth rates of juvenile bay scallops Argopecten irradians. J. Exp. Mar. Biol. Ecol. 129:45-60.

Centoducati, G., E. Tarsitano, A. Bottalico, M. Marvulli, O. Lai \& G. Crescenzo. 2007. Monitoring of the endangered Pinna nobilis Linné, 1758 in the Mar Grande of Taranto (Ionian Sea, Italy). Environ. Monit. Assess. 131:339-347.

Coutteau, P., K. Curé \& P. Sorgeloos. 1994. Effect of algal ration on feeding and growth of juvenile Manila clam Tapes philippinarum. J. Shellfish Res. 13:47-55.

Coutteau, P. \& P. Sorgeloos. 1992. The use of algal substitutes and the requirement for live algae in the hatchery and nursery rearing of bivalve molluscs: an international survey. J. Shellfish Res. 11:467476.

EEC. 1992. Council directive on the conservation of natural habitats and of wild fauna and flora (the habitats and species directive), ed. EEC. Official Journal of the European Communities.

Galinou-Mitsoudi, S., G. Vlahavas \& O. Papoutsi. 2006. Population study of the protected bivalve Pinna nobilis (Linnaeus, 1758) in Thermaikos Gulf (North Aegean Sea). J. Biol. Res. 5:47-53.
García-March, J. R. \& J. F. Ferrer. 1995. Biometría de Pinna nobilis L., 1758: una revisión de la ecuación de De Gaulejac y Vicente (1990). Bol. Inst. Esp. Oceanogr. 11:175-181.

García-March, J. R., A. M. Garcia-Carrascosa \& A. L. Pena. 2002. In situ measurement of Pinna nobilis shells for age and growth studies: a new device. Mar. Ecol. (Berl.) 23:207-217.

García-March, J., A. García-Carrascosa, A. Peña Cantero \& Y. G. Wang. 2007a. Population structure, mortality and growth of Pinna nobilis Linnaeus, 1758 (Mollusca, Bivalvia) at different depths in Moraira Bay (Alicante, western Mediterranean). Mar. Biol. 150:861-871.

García-March, J. R. \& A. Marquez-Aliaga. 2007b. Pinna nobilis L., 1758 age determination by internal shell register. Mar. Biol. 151: $1077-1085$.

Garcia-March, J. R., A. Marquez-Aliaga, Y. G. Wang, D. Surge \& D. K. Kersting. 2011. Study of Pinna nobilis growth from inner record: how biased are posterior adductor muscle scars estimates? J. Exp. Mar. Biol. Ecol. 407:337-344.

Gosling, E. 2007. Bivalve Culture, Chapter 9. In: Bivalve Molluscs: Biology, Ecology and Culture. pp. 284-332. Blackwell Publishing Ltd, Oxford, UK.

Huxley, J. S. 1932. Problems of relative growth. L. MacVeagh, The Dial Press, New York. 246 pp.

Katsanevakis, S. 2007. Growth and mortality rates of the fan mussel Pinna nobilis in Lake Vouliagmeni (Korinthiakos Gulf, Greece): a generalized additive modelling approach. Mar. Biol. 152:13191331.

Katsanevakis, S., M. Thessalou-Legaki, C. Karlou-Riga, E. Lefkaditou, E. Dimitriou \& G. Verriopoulos. 2007. Information-theory approach to allometric growth of marine organisms. Mar. Biol. 151: 949-959.

Kheder, R., C. Quéré, J. Moal \& R. Robert. 2010. Effect of nutrition on Crassostrea gigas larval development and the evolution of physiological indices. Part A: quantitative and qualitative diet effects. Aquaculture 305:165-173.

Moreteau, J. \& N. Vicente. 1982. Evolution d'une population de Pinna nobilis L. (Mollusca, Bivalvia). Malacologia 22:341-345.

Ogle, D. 2011. Package 'FSA' Version 0.2-7. Available at: http:// www.rforge.net/FSA/. Accessed November 2011. 
Rabaoui, L., S. Tlig Zouari, S. Katsanevakis \& O. Ben Hassine. 2007. Comparison of absolute and relative growth patterns among five Pinna nobilis populations along the Tunisian coastline: an information theory approach. Mar. Biol. 152:537548 .

Richardson, C. A., H. Kennedy, C. M. Duarte, D. P. Kennedy \& S. V. Proud. 1999. Age and growth of the fan mussel Pinna nobilis from south-east Spanish Mediterranean seagrass (Posidonia oceanica) meadows. Mar. Biol. 133:205-212.

Richardson, C. A., M. Peharda, H. Kennedy \& V. Onofri. 2004. Age, growth rate and season of recruitment of Pinna nobilis (L) in the Croatian Adriatic determined from Mg:Ca and $\mathrm{Sr}: \mathrm{Ca}$ shell profiles. J. Exp. Biol. Ecol. 299:1-16.

Rico-Villa, B., J. R. Le Coz, C. Mingant \& R. Robert. 2006. Influence of phytoplankton diet mixtures on microalgae consumption, larval development and settlement of the Pacific oyster Crassostrea gigas (Thunberg). Aquaculture 256:377-388.
Shimeta, J. \& P. A. Jumars. 1991. Physical mechanisms and rates of particle capture by suspension feeders. Oceanography and Marine Biology an Annual Review 29:191-275.

Shimeta, J. \& P. A. Jumars. 1991. Physical mechanisms and rates of particle capture by suspension feeders. In: M. Barnes, ed., Oceanography and Marine Biology an Annual Review, pp. 191-275. Aberdeen University Press.

Vicente, N., J. Moreteau, \& P. Escoubet 1980. Etude de l'evolution d'une population de Pinna nobilis L. (mollusque eulamellibranche) au large de l'anse de la Palud (Parc National sous-marin de PortCros). Trav. Scient. Parc Natn. Port-Cros 6:39-68.

von Bertalanffy, L. 1938. A quantitative theory of organic growth: inquiries on growth laws II. Hum. Biol. 10:181-213.

Zavodnik, D., M. Hrs-Brenko \& M. Legac. 1991. Synopsis on the fan shell Pinna nobilis L. in the eastern Adriatic Sea. In: C. F. Boudourescque, M. Avon \& V. Gravez, editors. Les especes marines a protéger en Méditerranée. Marseille: GIS Posidonie. pp 169-178. 